\title{
Sumber Daya Kesehatan dalam Penyusunan Perencanaan Dinas Kesehatan Kabupaten Padang Pariaman
}

\author{
The Sources of Health in Implementation of Planning at Dinas Kesehatan \\ Kabupaten Padang Pariaman
}

Jasrida Yunita*

*Staf Pengajar Prodi Pascasarjana IKM STIKes Hang Tuah Pekanbaru

\begin{abstract}
Abstrak
Perencanaan merupakan inti kegiatan manajemen, karena semua kegiatan manajemen diatur dan diarahkan oleh perencanaan tersebut. Kurang sempurnanya usulan perencanaan bisa disebabkan oleh kekurangan dibagian sumber daya seperti kebijakan, tenaga, dana, sarana prasarana, serta data dan informasi. Dalam dua tahun terakhir di Dinas Kesehatan Kabupaten Padang Pariaman terjadi kecenderungan penurunan capaian indikator program kesehatan. Hal ini salah satunya disebabkan oleh kurang sempurnanya perencanaan program dan kegiatan yang direncanakan setiap tahunnya. Tujuan penelitian diketahuinya sumber daya kesehatan dalam penyusunan perencanaan Dinas Kesehatan Kabupaten Padang Pariaman. Metode penelitian menggunakan pendekatan kualitatif dengan teknik wawancara mendalam dengan 12 orang informan. Hasil penelitian menyatakan pelaksanaaan penyusunan perencanaan telah mengikuti kebijakan yang sesuai dengan ketentuan dan perundangan yang berlaku, kualitas tenaga perencana dan data yang masih kurang, sarana dan prasarana yang cukup memadai tapi masih kurang dalam hal pemeliharaan serta dana yang sudah tersedia. Agar perencanaan berkualitas, maka perlu pelatihan tenaga perencana, penempatan tenaga sesuai keahliannya dan membentuk tim khusus dalam pengolahan data.

Kata kunci: Sumber Daya Kesehatan, Perencanaan, Dinas Kesehatan Kabupaten Padang Pariaman

\section{Abstract}

Planning is the core management activities, because all management activities are organized and directed by the plan. Defective planning proposal could be caused of deficiencies in the sources like are policy, human resources, funding, infrastructure, data and information. In the last two years at Dinas Kesehatan Padang Pariaman it occured trends decreasing indicators achievement of health programs. This is one of them caused by defective planning programs and activities that are planned each year. The purpose of this research will know the sources of health in implementation of planning at Dinas Kesehatan Kabupaten Padang Pariaman. The research method uses a qualitative approach with using the technique of personal interviews with 17 informants. The results from the component inputs explain the implementation of program planning has been followed in accordance with applicable rules and regulations, planners quality and data are still lacking, facilities and infrastructure are sufficient but still less in terms of maintenance, funds have available. In order for planning has quality, it is necessary training for planners, the placement of specific areas of expertise and to make a skilled of team in data processing.
\end{abstract}

Key words: Sources of health, planning, Dinas Kesehatan Kabupaten Padang Pariaman

Alamat Korespodensi : Jasrida Yunita, Prodi Pascasarjana IKM STIKes Hang Tuah Pekanbaru Jln. Mustafa Sari No 5 Tangkerang Selatan Pekanbaru, HP: 081371919944 email : jasridayunita@yahoo.com 


\section{Pendahuluan}

Perencanaan merupakan inti kegiatan manajemen, karena semua kegiatan manajemen diatur dan diarahkan oleh perencanaan tersebut. Dengan perencanaan tersebut memungkinkan para pengambil keputusan atau manajer untuk menggunakan sumber daya mereka secara berhasil guna dan berdaya guna (Notoatmodjo, 2007). Sedangkan perencanaan kesehatan adalah sebuah proses untuk merumuskan masalahmasalah kesehatan yang berkembang di masyarakat, menentukan kebutuhan dan sumber daya yang tersedia, menetapkan tujuan program yang paling pokok dan menyusun langkah-langkah praktis untuk mencapai tujuan yang telah ditetapkan (Muninjaya, 2004).

Selama tiga dekade terakhir ini, hasil dari perencanaan kesehatan telah berhasil meningkatkan pelayanan kesehatan dasar secara lebih merata sehingga dapat menurunkan angka kematian bayi dan balita, meningkatkan kesehatan ibu dan anak, meningkatkan keadaan gizi masyarakat dan memperpanjang harapan hidup rata-rata penduduk. Namun dalam beberapa tahun terakhir, pembangunan kesehatan menghadapi tantangan yang cukup besar dalam mempertahankan peningkatan status kesehatan masyarakat. Indikasi ini terlihat dari melambatnya penurunan kematian ibu, kematian bayi dan meningkatnya kekurangan gizi pada balita (Bappenas, 2009).

Berdasarkan data SDKI tahun 2007, Angka Kematian Ibu (AKI) di Indonesia adalah 228 per 100.000 kelahiran hidup, Angka Kematian Bayi (AKB) adalah 34 per 1000 kelahiran hidup dan umur harapan hidup (UHH) adalah 70,5 tahun. Sedangkan prevalensi kekurangan gizi pada balita menurut Riskesdas (2007) adalah sebesar 18,4\%.

Di Propinsi Sumatera Barat, pada tahun 2007 dilaporkan AKI sekitar 229 per
100.000 kelahiran hidup, AKB sekitar 34 per 1.000 kelahiran hidup dan UHH adalah 68,8 tahun (Sumbar, 2008). Sedangkan untuk prevalensi kekurangan gizi pada balita menurut Riskesdas Sumbar (2007) sekitar $20 \%$.

Berdasarkan target yang ditetapkan dalam Millenium Development Goals (MDGs) untuk tahun 2015 diantaranya menurunkan AKI menjadi 110 per 100.000 kelahiran hidup dan menurunkan AKB menjadi 19 per 1.000 kelahiran hidup, maka hasil yang telah dicapai sampai saat ini masih jauh dari target. Untuk mencapai itu semua maka dalam perencanaan kesehatan yang akan datang perlu ditekankan pada program dan kegiatan yang langsung mengena pada penurunan AKI dan AKB ini.

Tantangan dalam meningkatkan derajat kesehatan masyarakat ini juga dihadapai oleh Kabupaten Padang Pariaman yang merupakan salah satu kabupaten yang ada di Propinsi Sumatera Barat, juga berupaya dalam menurunkan angka kematian terutama AKI dan AKB. Ini terbukti dengan adanya program upaya kesehatan masyarakat dalam menurunkan AKI dan AKB ini dalam RPJMD Kabupaten Padang Pariaman tahun 20062010 (Padang Pariaman, 2008).

Program upaya kesehatan masyarakat ini merupakan tanggung jawab dari Dinas Kesehatan Kabupaten Padang Pariaman sebagai salah satu SKPD yang ada di Pemerintah Daerah (Pemda) Kabupaten Padang Pariaman. Sejalan dengan RPJMD Kabupaten Padang Pariaman, Dinas Kesehatan Kabupaten Padang Pariaman juga memprioritaskan program dan kegiatannya terhadap penurunan angka kematian terutama AKI dan AKB.

Apabila dilihat dari pencapaian indikator kinerja kunci (IKK) yang terdapat dalam standar pelayanan minimal (SPM) Dinas Kesehatan Kabupaten Padang Pariaman dalam dua tahun terakhir 
ini, masih ada beberapa indikator yang belum mencapai target. Diantaranya ibu hamil resti dirujuk (target 100\%) mengalami penurunan dari $85 \%$ pada tahun 2008 menjadi $13,33 \%$ pada tahun 2009; Neonatal resti dan komplikasi ditangani (target 80\%) mengalami penurunan dari $84,07 \%$ tahun 2008 menjadi $46 \%$ pada tahun 2009; pertolongan persalinan oleh bidan/tenaga ahli (target 90\%) mengalami penurunan dari $82,9 \%$ pada tahun 2008 menjadi $79,1 \%$ pada tahun 2009; $98 \%$ Universal Child Immunization (UCI) sampai akhir tahun 2009 juga belum tercapai tetapi mengalami peningkatan dari $85 \%$ pada tahun 2008 menjadi 87\% pada tahun 2009; dan cakupan kunjungan bayi (target 90\%) juga mengalami penurunan dari $99,6 \%$ pada tahun 2008 menjadi $80 \%$ pada tahun 2009 (Padang Pariaman, 2010).

Apabila kita perhatikan capaian indikator kesehatan tersebut maka dapat terlihat kecenderungan terjadinya penurunan capaian indikator program dalam dua tahun terakhir ini. Hal ini salah satunya disebabkan oleh kurang sempurnanya perencanaan program dan kegiatan yang direncanakan setiap tahunnya. Kegiatan yang dilaksanakan salah satunya belum mengena kepada pencapaian target tersebut. Bencana gempa bumi yang terjadi pada 30 September 2009 lalu juga dianggap sebagai salah satu faktor menurunnya capaian program. Hal ini disebabkan banyaknya sarana dan prasarana yang rusak seperti runtuhnya bangunan puskesmas, pustu, polindes/poskesri dan rendahnya capaian PHBS karena banyak rumah yang roboh serta meningkatnya angka kesakitan.

Dimasa yang akan datang Dinas Kesehatan Kabupaten Padang Pariaman mempunyai tugas yang berat untuk mencapai semua program yang telah ditetapkan terutama dalam pencapaian indikator kinerja kunci. Untuk itu diperlukan sebuah dokumen perencanaan yang baik sebagai acuan dalam pelaksanaan kegiatan. Dalam penyusunan dokumen perencanaan tidak lepas dari sumber daya kesehatan yang menunjang penyusunan perencanaan diantaranya kebijakan yang telah ditetapkan oleh pemerintah, tenaga perencana kesehatan, sumber daya dana, sarana dan prasarana serta data dan informasi kesehatan.

Dari wawancara yang dilakukan dengan beberapa pegawai Dinas Kesehatan Kabupaten Padang Pariaman menyatakan bahwa belum pernah dilakukan penelitian tentang kebijakan yang mengatur penyusunan perencanaan, kemampuan sumber daya tenaga dalam penyusunan perencanaan, anggaran dana dalam penyusunan perencanaan, sarana dan prasarana yang menunjang penyusunan perencanaan, serta data dan informasi yang dimanfaatkan dalam penyusunan perencanaan. Maka dari itu penulis tertarik melakukan penelitian tentang sumber daya kesehatan dalam penyusunan perencanaan Dinas Kesehatan Kabupaten Padang Pariaman.

Tujuan dari penelitian ini adalah diketahui sumber daya kesehatan dalam penyusunan perencanaan Dinas Kesehatan Kabupaten Padang Pariaman.

\section{Metode}

Metode penelitian menggunakan pendekatan kualitatif yang dilaksanakan di Dinas Kesehatan Kabupaten Padang Pariaman tahun 2010 dengan menggunakan teknik wawancara mendalam dengan 12 orang informan yang terlibat dalam penyusunan perencanaan di Dinas Kesehatan Kabupaten Padang Pariaman. Instrumen penelitian menggunakan pedoman wawancara mendalam, alat pencatat dan alat perekam. Teknik pengumpulan data dengan metode wawancara mendalam, observasi dan telaah dokumen. Data dianalisis dengan teknik analisis kualitatif. Untuk menjaga validitas data dilakukan dengan metode triangulasi sumber dan data. Informasi yang diperlukan adalah informasi tentang 
kebijakan, sumber daya tenaga, dana, sarana dan prasarana serta data dan informasi.

\section{Hasil}

\section{Kebijakan}

Kebijakan di era otonomi ini, memungkinkan daerah untuk membuat sendiri perencanaannya. Dalam menyusun perencanaan ada aturan-aturan yang ditetapkan sebagai pedoman ataupun acuan dalam penyusunan perencanaan, diantaranya Dinas Kesehatan mengacu ke RPJPN, RPJPD, RPJMN, RPJMD, Renstra, Peraturan Bupati, maupun aturanaturan lainnya seperti yang disampaikan informan berikut ini:

"Perencanaan itu mengacu kepada
tahun yang sebelumnya, yaitu
mengutamakan program-program
mana yang belum terselesaikan (kenapa
belum selesai?) jadi untuk tahun
berikutnya itu diprioritaskan lagi,
dimana masalahnya? Kita cari
kegiatan-kegiatan apa yang dapat
mendukung penyelesaian program tadi.
Selain itu kita juga mengaitkannya
dengan RPJPN, RPJPD, RPJMN,
RPJMD, visi misi bupati karena
dokumen-dokumen perencanaan tetap
mengacu kesitu.".

Informan 1

"Kebijakan dalam menyusun perencanaan disini berpedoman pada Permendagri 13/2006. Selain itu ada juga Perbup no. 20 tahun 2009 tentang Petunjuk Teknis Pelaksanaan. Perbup ini ada dikeluarkan tiap tahunnya. Disini nanti dijelaskan berapa anggaran biaya untuk suatu kegiatan, misalnya perjalanan dinas".

Informan 7

Beberapa informan juga berpendapat bahwa kebijakan dalam penyusunan perencanaan juga tidak terlepas dari skala prioritas masalah, data dan anggaran dana, seperti yang disampaikan informan berikut ini:

"Dalam penyelesaian kita juga mengacu ke data dan disesuaikan dengan pendanaan-pendanaannya. Kebijakan juga termasuk kondisi saat ini, misal DBD tinggi jadi kita prioritaskan kegiatan kesitu dengan tidak mengabaikan program yang tidak tercapai tahun sebelumnya”.

Informan 1

"Dalam penyusunan perencanaan kita selalu berangkat dari prioritas program. Apa yang prioritas itu yang diutamakan. Selain itu kebijakan terkait dengan dana juga akan mempengaruhi perencanaan yang dibuat”.

\section{Informan 2}

Hasil telaah dokumen diketahui bahwa di Dinas Kesehatan Kabupaten Padang Pariaman dalam penyusunan perencanaan mengacu ke Permendagri No. 13 tahun 2006, Permendagrai no. 59 tahun 2007 dan juga Peraturan Bupati tentang Petunjuk Teknis Pelaksanaan yang ditetapkan setiap tahunnya. Selain itu dalam menyusun program dan kegiatan telah mengacu kepada RPJMD Kabupaten Padang Pariaman 2006-2010 dan Renstra Dinas Kesehatan Propinsi maupun Pusat. Program maupun indikator program yang ada didalam RPJMD Kabupaten Padang Pariaman 2006-2010 telah dituangkan dalam Renstra Dinas Kesehatan Kabupaten Padang Pariaman dan indikator yang tidak ada dalam RPJMD Kabupaten Padang Pariaman 2006-2010 tetapi terdapat dalam Renstra Dinas Kesehatan Propinsi maupun Pusat ditambahkan sebagai indikator program dalam Renstra Dinas Kesehatan Kabupaten Padang Pariaman 2006-2010, seperti dalam program penyehatan lingkungan dan pemberantasan penyakit dimasukkan indikator $98 \%$ Universal Child Immunization (UCI) dan 100\% penderita malaria yang deiobati. Dalam 
LAKIP juga ditemukan beberapa kegiatan yang belum mencapai target di tahun 2009 diusulkan lagi dalam perencanaan tahun 2010.

\section{Sumber daya tenaga}

Dilihat dari segi jumlah sumber daya tenaga perencana di Dinas Kesehatan Kabupaten Padang Pariaman sudah mencukupi, apalagi sekarang dalam penyusunan perencanaan sudah dibentuk Tim Penyusunan Capaian Kinerja dan Perencanaan Pembangunan. Dalam tim ini hampir semua pejabat di struktural terlibat, kecuali untuk seksi-seksi hanya mewakili satu orang dari tiap-tiap bidang, seperti disampaikan informan berikut ini:

"Disini ada tim yang dibentuk untuk penyusunan perencanaan ini. Tim perencanaan ini ada SK-nya yang terdiri dari penanggung jawab yaitu Kadis, wakil penanggung jawab adalah sekretaris, ketua tim yaitu Kasubbag Perencanaan, sekretaris dari staf perencanaan, tim perumus dari masingmasing Kabid, anggota perangkum terdiri dari Kasie masing-masing bidang dan beberapa orang tim Simda".

Informan 3

"Tim ini sudah mulai dibentuk sejak dikeluarkannya Perrmendagri no 13/2006. Setiap tahun ada SK-nya yang dikeluarkan oleh Kadis. Tim ini dibentuk juga karena usulan dari Bappeda untuk dibentuk tim penyusunan laporan capaian kinerja dan perencanaan pembangunan”.

Informan 12

Perencanaan yang diusulkan berasal dari Kepala Seksi (kasie) yang nantinya dihimpun oleh Sub Bagian Perencanaan dan dijadikan dokumen Rencana Kerja Perangkat Daerah (RKPD/Renja SKPD), seperti disampaikan informan berikut ini:
"Yang terlibat dalam menyusun perencanaan masing-masing kasie sesuai dengan programnya masingmasing”.

Informan 4

"SDM yang terlibat dalam penyusunan perencanaan itu melibatkan staf. Seperti progrm jiwa kita membuatnya dengan staf di bagian jiwa, kalau mata dengan staf dibagian mata. Nanti hasilnya dikonsulkan ke Kabid, apabila sudah disetujui Kabid, baru dimasukkan ke Sub Bagian Perencanaan”.

Informan 10

Dari segi kualitas tenaga perencana beberapa informan mengungkapkan bahwa tenaga perencana cukup berkualitas dan paham dalam penyusunan perencanaan, seperti disampaikan informan berikut ini:

"Kalau bicara kualitas, saya rasa bagus karena selama ini tidak terlalu ada kendala dari tiap Kasie dalam menyusun perencanaan. Perencanaan disusun sesuai format ataupun aturan yang ditetapkan”.

Informan 4

Beberapa informan berpendapat lain tentang kualitas tenaga perencana seperti disampaikan berikut ini:

"Disini ada tenaga perencana umum dan tenaga perencana kesehatan. Antara perencanaan umum dengan perencana kesehatan itu tidak bisa disamakan, Kalau kesehatan pekerjaannya spesifik, seperti dimulai dari kasie-kasie, kabid-kabid, kemudian masuk ke subbag perencanaan (perencana umum) yang menyusun/merapikan perencanaan dari perencana kesehatan. Kalau orang kesehatan yang duduk di perencanaan umum ini tentunya bisa membetulkan program-program yang diusulkan. Tetapi karena sejak otonomi ini kita tidak bisa terlalu berharap 
mendapatkan tenaga yang sesuai bidangnya, karena siapa saja yang bukan berlatar belakang kesehatan bisa masuk disini".

\section{Informan 1}

"Kalau dilihat dari latar belakang pendidikannya, tenaga disini masih ada juga yang bukan dari kesehatan. Bagaimanapun juga, yang betul-betul paham akan kesehatan pasti orangorang yang berlatar belakang kesehatan".

Informan 2

Menurut salah satu informan mengungkapkan bahwa lemahnya perencanaan karena sering terjadi pergantian pejabat struktural dan pejabat yang diangkat juga sering tidak sesuai dengan kompetensi yang dibutuhkan, seperti disampaikan informan berikut ini:

"Lemahnya perencanaan karena seringnya pergantian pejabat struktural dan tenaga yang diangkat juga tidak sesuai dengan kompetensi yang dibutuhkan".

Informan 2

Untuk pelatihan tentang perencanaan (P2KT) sebagian dari informan sudah pernah mengikutinya dan sebagian lain belum pernah karena masih baru menjabat diposisi sekarang, seperti disampaikan informan berikut ini:

"Untuk pelatihan P2KT diantara staf disini ada yang sudah dan ada juga yang belum, kalau saya sendiri karena masih baru disini belum pernah mengikuti pelatihan tersebut. Biasanya yang mengikuti ini baru Kabid”.

Informan 10

"Dulu pernah ada pelatihan P2KT tapi orang-orang ini tidak dilibatkan atau banyak yang pindah. Sedangkan sekarang banyak tenaga baru yang terlibat dalam perencanaan sedangkan tenaga ini belum dilatih. Dengan mengikuti pelatihan ini kita paham dengan perencanaan”.

Informan 11

Hambatan yang ada terkait sumber daya tenaga adalah kurangnya staf hampir ditiap seksi, seperti ungkapan informan berikut ini:

"Kalau dari segi jumlah tenaga memang kurang, staf disini juga dilibatkan diseksi yang lain. Di Promkes ada tiga seksi, staf yg terlibat cuma dua orang untuk ketiga seksi tadi. Minimal tiap seksi ada 2 staf lah disana”.

Informan 11

Saran terkait dengan sumber daya tenaga adalah penyusun program paham akan programnya, pemegang program minimal berlatar pendidikan S1 Kesehatan/SKM, tenaga perencana diberi pelatihan perencanaan dan perlunya kemampuan melobi bagi tenaga perencana, seperti yang disampaikan oleh informan berikut:

"Sarannya kalau bisa penyusunpenyusun program memahami programnya, setelah program paham, dibuat, diajukan dan bisa untuk ditindak lanjuti”.

Informan 1

"Kalau dapat seluruh pemegang program minimal berpendidikan $S 1$ kesehatan/SKM karena orang-orang inilah yang memang mengerti administrasi kesehatan”.

Informan 2

"Ada tidaknya dana terkait melobi juga, mestinya tim perencana yang ikut rapat perencanaan dengan kepala dinas harus bisa melobi bahwa kegiatan ini penting, kadang kasie tidak diajak padahal yang tahu permasalahan ini dikasie. Kemudian 
juga perlu kemampuan melobi di DPRD”.

Informan 9

Dari telaah dokumen diketahui bahwa perencanaan di Dinas Kesehatan Kabupaten Padang Pariaman disusun oleh tim yang telah dibentuk, dimana anggotanya terdiri dari Kepala Dinas sebagai penanggung jawab, Sekretaris sebagai wakil penanggung jawab, Kepala Sub Bagian Perencanaan sebagai ketua, Staf Sub Bagian Perencanaan sebagai sekretaris, semua Kepala Bidang (Kabid) sebagai tim perumus, Kasie dari masingmasing bidang sebagai anggota perangkum dan beberapa orang tim sekretariat/simda. Tim perumus serta anggota perangkum merupakan anggota tim yang merumuskan serta merangkum program-program yang akan direncanakan. Latar belakang pendidikan tenaga perencana kesehatan seperti tim perumus (Kabid) serta anggota perangkum (Kasie) masih ada yang tamatan Diploma serta masih ada yang berlatar belakang bukan dari kesehatan. Sedangkan anggota tim lainnya juga ada beberapa orang yang berlatar belakang bukan kesehatan. Untuk pangkat dan golongan dari pegawai struktural yang berperan sebagai tenaga perencana dimulai dari pangkat Pembina Utama Muda/IV c sampai Penata Muda/III a.

\section{Dana}

Untuk penyusunan perencanaan di
Dinas Kesehatan Kabupaten Padang Pariaman ada anggaran dana dialokasikan yang bersumber dari APBD Kabupaten Padang Pariaman. Dana ini dimasukkan dalam Urusan Wajib Dinas Kesehatan Kabupaten Padang Pariaman. Dana untuk penyusunan perencanaan masuk dalam Program Peningkatan Pengembangan Sistem Pelaporan Capaian Kinerja dan Keuangan. Anggaran ini termasuk untuk biaya rapat, pembelian ATK, biaya perbanyak dan penjilidan serta biaya lembur pegawai, seperti yang disampaikan oleh informan berikut:
"Dalam penyusunan perencanaan ini, ada dana yang dianggarkan. Sumbernya dari APBD II. Untuk dana ini kita yang mengajukan, biasanya dana ini dianggarkan untuk biaya kertas, memperbanyak serta menjilid dan juga untuk lembur sama biaya rapat-rapat”.

Informan 12

Salah satu informan menyatakan bahwa dana yang ada jumlahnya masih dalam batas minimal sehingga seharusnya ada pertemuan berkala jadinya dilakukan beberapa kali saja, seperti ungkapan informan berikut:

"Saran saya dana ditambah, yang saya dengar ada dana dianggarkan untuk perencanaan tapi itu sepertinya batasbatas minimal. Misalnya seharusnya ada pertemuan berkala sekian kali, tapi karena kurangnya dana bisa jadi pertemuan ini diadakan sekali dua kali saja”.

\section{Informan 11}

Dari hasil telaah dokumen diketahui bahwa ada alokasi dana yang dianggarkan untuk kegiatan penyusunan perencanaan. Anggaran dana ini termasuk kedalam Program Peningkatan Pengembangan Sistem Pelaporan Capaian Kinerja dan Keuangan. Kegiatan yang masuk dalam program ini adalah penyusunan laporan capaian kinerja dan ikhtisar realisasi kinerja SKPD dengan indikator keluaran adalah penyusunan LAKIP, RKPD, Renja, PPA dan TAPKIN serta RKA dan indikator hasilnya adalah tersedianya dokumen RKA, DPA dan LAKIP.

\section{Sarana dan prasarana}

Sarana dan prasarana yang menunjang kelancaran proses penyusunan perencanaan tahunan di Dinas Kesehatan Kabupaten Padang Pariaman cukup memadai. Dari hasil wawancara mendalam dapat disimpulkan bahwa sarana dan 
prasarana yang menunjang penyusunan perencanaan cukup tersedia, seperti yang disampaikan informan berikut ini:

"Sarana prasarana tersedia lengkap. Baik itu komputer maupun printer. Mobil dinas ada yang bisa digunakan untuk konsultasi ke Pemda ataupun mengikuti rapat-rapat di Pemda".

Informan 3

"Untuk sarana prasarana seperti komputer, sarana komunikasi serta transportasi tersedia lengkap. Tidak ada masalahlah dengan sarana prasarana ini”.

Informan 12

Hambatan terkait sarana dan prasarana diungkapkan oleh informan berikut:

"Komputer yang kurang disini, ada satu sudah rusak, laptop satu itupun perlu instal ulang sering ada virus. Kalau printer disini ada dan masih bagus. Untuk mengatasi kekurangan komputer, disini kasie membawa laptop pribadi dari rumah masing-masing”.

Informan 6

"Komputer disini ada yang bagus satu buah dan itu digunakan bersama-sama. Kendala yang ada, kadang waktu penyusunan perencanaan bersamaan dengan pengerjaan tugas lain. Jadi harus gantian dulu. Tetapi secara umum itu tidak terlalu jadi masalah”.

\section{Informan 13}

Dari pengamatan dan laporan sarana dan prasarana ada tersedia sarana komputer ditiap seksi, untuk Subbag Perencanaan juga tersedia 1 buah komputer beserta printer dengan ruangan yang cukup memadai. Untuk alat transportasi dan komunikasi ada tersedia tetapi untuk perencanaan tidak ada tersedia khusus. Dan juga ditemukan ada beberapa komputer yang tidak dipergunakan lagi (rusak/perlu instal ulang).

\section{Data dan informasi}

Data maupun informasi yang ada di Dinas Kesehatan Kabupaten Padang Pariaman sudah dimanfaatkan dalam penyusunan perencanaan dan beberapa informan mengatakan bahwa data tersedia lengkap, seperti disampaikan informan berikut ini:

"Data tersedia lengkap, biasanya kita menggunakan Profil, LAKIP maupun laporan bulanan puskesmas. Masalah terkait data dalam menyusun perencanaan rasanya tidak ada".

Informan 6

Sebagian dari informan berpendapat bahwa data memang tersedia tetapi belum lengkap dan keakuratannya juga masih dipertanyakan, seperti disampaikan informan berikut ini:

"Data kita dapat dari lapangan, valid tidaknya data itu yang membuat yang tahu. Disini kita ada tersedia data yang digunakan sebagai acuan dalam merencanakan program dan kegiatan. Dalam menyusun rencana kita tetap berbasis data".

Informan 1

"Data untuk penyusunan perencanaan tersedia, tetapi apakah data ini valid atau tidak itu yang perlu dipertanyakan karena orang-orang yang ditugaskan dibagian pengumpulan maupun pengolahan data juga bukan orangorang yang ahli dibidangnya”.

Informan 2

"Data kurang lengkap, karena tidak semua puskesmas yang lengkap memberikan data. Untuk data 2009 belum lengkap $100 \%$ kira-kira baru 80\%. Data yang ada diolah oleh bagian evapor. Kalau terkait data saya rasa tidak terlalu ada masalah, karena data yang terkumpul sudah lebih 75\%, maka kami anggap masalah didaerah lain hampir sama”. 
Informan 10

Saran yang diberikan informan terkait data dan informasi ini adalah sebagai berikut:

"Sarannya kalau dapat seluruh puskesmas cepat mengumpulkan data. Biasanya yang sering telat puskesmas yang jauh-jauh. Biasanya terlambat karena tenaga pengolah data disana tidak cukup. Saran lain kalau dapat seluruh puskesmas ada tenaga pengolah data. Sebelumnya sudah ada SIK, tapi karena gempa, komputer SIK rusak, kalau dapat cepat diperbaiki sehingga puskesmas yang jauh tinggal mengirim kan data lewat internet”.

Informan 10

"Sarannya minimal masing-masing seksi ada 2 staf, sehingga bisa mengelola data tadi, jadi bukan orangorang yang itu-itu saja yang terlibat disemua kegiatan”.

\section{Informan 11}

Dari hasil telaah dokumen terkait ketersediaan dan pemanfaatan data dalam penyusunan perencanaan tahunan di Dinas Kesehatan Kabupaten Padang Pariaman sudah memanfaatkan data laporan dari puskesmas (SP2TP), LPLPO, LAKIP dan laporan hasil survey. Data dari puskesmas belum pernah ditinjau ulang kebenarannya dan tenaga pengolah data di Dinas Kesehatan Kabupaten Padang Pariaman juga bukan tenaga yang ahli dibidangnya.

\section{Pembahasan}

\section{Kebijakan}

Hasil temuan di Dinas Kesehatan Kabupaten Padang Pariaman terkait penyusunan perencanaan khususnya untuk tahun 2010 sudah mengacu kepada kebijakan-kebijakan yang telah ditetapkan oleh pemerintah pusat maupun kebijakan pemerintah daerah sendiri, seperti mengacu kepada RPJMD, Renstra pusat, renstra propinsi maupun renstra Dinas Kesehatan Kabupaten Padang Pariaman.
Dengan adanya renstra yang dijadikan acuan dalam perencanaan tahunan, maka akan memudahkan dalam penetapan program dan kegiatan yang akan direncanakan. Acuan lain dalam penyusunan selain Renstra dan RPJMD juga berpedoman kepada undang-undang maupun peraturan yang berlaku seperti mengacu pada Undang-undang no 25 tahun 2004, Permendagri no. 13 tahun 2006 ataupun Permendagri no. 59 tahun 2007 serta mengacu juga pada peraturanperaturan daerah.

Dalam peraturan dan perundangan baru, penyusunan rencana dikehendaki memadukan pendekatan teknokratis, demokratis, partisipatif, politis, bottom-up dan top down process. Ini bermakna bahwa perencanaan daerah selain diharapkan memenuhi kaidah penyusunan rencana yang sistematis, terpadu, transparan dan akuntabel, konsisten dengan rencana lainnya yang relevan, juga kepemilikan rencana (sense of ownership) menjadi aspek yang perlu diperhatikan. Keterlibatan stakeholder dan legislatif dalam proses pengambilan keputusan perencanaan menjadi sangat penting untuk memastikan rencana yang disusun mendapatkan dukungan optimal bagi implementasinya (LGSP, 2007)

Dalam penyusunan Renja juga menekankan tentang pentingnya SKPD menguasai dan kompeten dalam menyusun program dan kegiatan SKPD sesuai Permendagri 13/2006 dan Permendagri no. 59 tahun 2007 tentang Pedoman Pengelolaan Keuangan Daerah, karena Renja SKPD merupakan dasar utama bagi penyusunan rencana dan penganggaran tahunan. Kualitas penyusunan Renja SKPD akan sangat menentukan kualitas rencana daerah diatasnya.

\section{Sumber Daya Tenaga}

Dalam proses penyusunan perencanaan di Dinas Kesehatan Kabupaten Padang Pariaman sudah dibentuk tim khusus perencanaan 
kesehatan yang beranggotakan pejabat struktural mulai dari eselon II sampai eselon IV dan mempunyai tugas menyusun perencanaan tahunan mulai dari merumuskan, merangkum dan membahas usulan program dan kegiatan kesehatan. Tetapi fungsi tim ini belum berjalan secara maksimal karena usulan program dan kegiatan masih berasal dari usulan seksi.

Dalam tupoksi anggota tim disebutkan bahwa tugas merangkum program dan kegiatan yang akan direncanakan adalah tugas anggota perangkum yang dijabat oleh seksi dari tiap-tiap bidang dan dirumuskan oleh tim perumus (Kabid). Tetapi dalam pelaksanaannya peran tim perumus kurang maksimal karena masih adanya persepsi bahwa yang menyusun perencanaan adalah seksi (Button up planning). Padahal dalam peraturan perundang-undangan yang baru selain pendekatan Button up planning juga disertai dengan top down process.

Menurut Bakri (2001) agar proses perencanaan berlangsung efektif, dibutuhkan suatu organisasi atau tim secara fungsional yang pada banyak negara dikenal sebagai District Health Management Team yang merupakan target group untuk penguatan manajemen kesehatan pada tingkat kabupaten/kota yang beranggotakan para penanggung jawab program kesehatan dan penanggung jawab administrasi. Dilibatkan atau tidak unsur rumah sakit kabuapaten/kota kedalam tim ini disesuaikan dengan kondisi lokal masing-masing daerah. Tim manajemen/perencana tersebut bertanggung jawab terhadap kelangsungan proses manajemen/perencanaan kesehatan kabupaten/kota termasuk dalam hal pengambilan kebijakan kesehatan lokal. Beberapa skill yang dibutuhkan oleh tim perencana kesehatan kabupaten/kota antara lain kemampuan menggunakan problem solving approach, kemampuan dalam penentuan prioritas, kemampuan dalam pengumpulan informasi yang relevan dan kemampuan dalam pengembangan komunikasi dan konsensus.

Penelitian Riyarto (2006)

menemukan bahwa analisis yang dilakukan di beberapa kabupaten dalam penyelenggaraan desentralisasi kesehatan menunjukkan bahwa diskes memerlukan tenaga profesional diantaranya adalah ahli administrasi atau perencana dan ekonomi kesehatan dan informasi kesehatan.

Sumber daya manusia merupakan faktor kunci keberhasilan dalam proses pembangunan kesehatan. Untuk itu diperlukan ketersediaan dan kemampuan sumber daya manausia agar dapat mengelola potensi yang ada di daerah serta dapat melakukan pengelola sumber daya yang lainnya secara efektif dan efidien sehingga dapat memberikan dampak positif terhadap pembangunan.

\section{Dana}

Di Dinas Kesehatan Kabupaten Padang Pariaman ditemukan bahwa dalam penyusunan perencanaan telah dianggarkan sejumlah dana guna kelancaran proses kegiatan penyusunan perencanaan terutama untuk tahun 2010 ini. Anggaran dana ini termasuk kedalam Program Peningkatan Pengembangan Sistem Pelaporan Capaian Kinerja dan Keuangan. Kegiatan yang masuk dalam program ini adalah penyusunan laporan capaian kinerja dan ikhtisar realisasi kinerja SKPD dengan indikator keluaran adalah penyusunan LAKIP, RKPD, Renja, PPA dan TAPKIN serta RKA dan indikator hasilnya adalah tersedianya dokumen RKA, DPA dan LAKIP.

Dalam penelitian Ernawati (2004) menyatakan bahwa dalam penyusunan perencanaan program pembangunan kesehatan, secara khusus harus disediakan dananya, karena sangat dibutuhkan untuk biaya operasional yang digunakan dalam pelaksanaan penyusunan perencanaan pembangunan kesehatan dengan harapan 
akan memperoleh kualitas perencanaan yang optimal.

Ketersediaan anggaran dana dalam penyusunan perencanaan sangat diperlukan walaupun besarnya berbedabeda ditiap kabupaten/kota, hal ini tergantung dari jenis serta jumlah kegiatan yang akan dilakukan, misalnya biaya operasional penyusunan perencanaan, biaya aparatur (lembur tenaga perencana) dan biaya lainnya yang dibutuhkan dalam penyusunan perencanaan.

\section{Sarana dan Prasarana}

Sarana dan prasarana seperti sarana komputer dan penunjang lainnya sudah memadai atau bukan merupakan hambatan dalam penyusunan perencanaan di Dinas Kesehatan Kabupaten Padang Pariaman, akan tetapi pemeliharaan terhadap sarana ini yang agak kurang karena ditemukan ada beberapa komputer yang tidak berfungsi termasuk komputer SIK serta laptop milik Dinas Kesehatan Kabupaten Padang Pariaman yang perlu diinstal ulang. Ini disebabkan karena belum adanya tenaga khusus yang bertugas dalam perawatan sarana seperti komputer ini. Disamping itu sebagian tenaga memanfaatkan laptop pribadi dalam menunjang pekerjaannya sehingga perhatian terhadap sarana kantor inipun agak kurang. Selain itu transportasi maupun alat komunikasi yang mendukung proses penyusunan perencanaan juga tersedia walaupun tidak ada sarana khusus untuk penyusunan perencanaan, namun tetap bisa memanfaatkan sarana yang ada. Dan saat ini komunikasi semakin dipermudah dengan adanya telepon selular (handphone).

Menurut Trisnantoro (2001) bahwa perancangan sistem dapat dikembangkan dengan berbasis pada komputer karena memiliki beberapa keunggulan. Keunggulan tersebut diantaranya sistem ini dapat mengakses data dalam jumlah besar dengan waktu yang singkat, serta hasil informasi yang diperoleh lebih akurat, tepat waktu dan lengkap.

Dalam Symond (2006) dijelaskan bahwa agar fungsi manajemen berjalan baik maka sangat diperlukan adanya fasilitas yaitu sarana dan peralatan yang dipakai untuk kelancaran perencanaan tersebut. Sarana dan prasarana sangat diperlukan guna menunjang kelancaran proses penyusunan perencanaan. Ketersediaan sarana dan prasarana yang memadai akan mempercepat proses penyusunan perencanaan itu sendiri.

\section{Data dan Informasi}

Di Dinas Kesehatan Kabupaten Padang Pariaman ditemukan bahwa sumber data yang dipergunakan dalam penyusunan perencanaan berasal dari laporan puskesmas dan Profil Dinas Kesehatan Kabupaten Padang Pariaman. Selain itu sumber data lain yang dipakai adalah hasil survey dan LAKIP Dinas Kesehatan Kabupaten Padang Pariaman. Akan tetapi data yang terkumpul saat ini masih kurang lengkap dan sumber data yang dimiliki belum terjamin kevalidannya terkait dengan tenaga pengumpul maupun pengolah data.

Kurang lengkapnya data disebabkan karena masih ada dari beberapa puskesmas yang sering telat menyerahkan laporan bulanan, triwulan maupun laporan tahunannya. Tetapi hal ini tidak terlalu jadi masalah oleh sebagian tenaga perencana karena dengan data yang ada saat ini dianggap cukup mewakili untuk melakukan analisis situasi dalam penentuan prioritas masalah. Padahal apabila diperhatikan pola maupun kecenderungan masalah kesehatan tidak sama ditiap wilayah. Apalagi wilayah Kabupaten Padang Pariaman yang terdiri dari wilayah pesisir dan wilayah perbukitan, tren penyakit diwilayah ini jelas berbeda.

Dari segi tenaga pengolah data masih dipegang oleh orang yang bukan 
ahli dibidangnya. Sehingga perlu waktu yang lama bagi tenaga ini untuk mempelajari tugas-tugasnya serta menyebabkan data-data yang ada mengalami proses yang lama baru menjadi sebuah informasi. Padahal informasi baik itu dari Profil maupun dari LAKIP sangat dibutuhkan sebagai data penunjang dalam penyusunan perencanaan.

Hasil penelitian Riyarto (2006) menunjukkan bahwa proses pengumpulan, pengolahan dan analisa data di masingmasing sub dinas maupun puskesmas tidak dilakukan secara profesional, sehingga banyak sumber data yang tidak sesuai dengan kondisi riil puskesmas dan dinas kesehatan. Dari beberapa penelitian lain terkait dengan perencanaan, menyatakan bahwa kelengkapan data dan informasi belum baik dan kemampuan SDM dalam mengolah data masih terbatas.

Data sangat dibutuhkan untuk mendukung terciptanya sebuah perencanaan yang baik. Tanpa adanya data maka sangat sulit untuk meyakinkan eksekutif maupun legislatif tentang perlunya alokasi anggaran kesehatan (Kuntjoro, 2004). Dengan demikian, penyusunan perencanaan kesehatan haruslah berbasis pada data. Untuk itu perlunya sistem database yang memadai guna kelancaran proses pengumpulan, pengolahan maupun analisis data.

\section{Kesimpulan}

1. Penyusunan perencanaan telah sesuai dengan kebijakan-kebijakan yang telah ditetapkan oleh pemerintah pusat maupun kebijakan pemerintah daerah sendiri serta mengacu kepada tahun sebelumnya dan juga mengacu kepada data (data base) serta disesuaikan dengan ketersediaan dana.

2. Sudah ada dibentuk tim penyusunan perencanaan namun tim ini belum berperan secara maksimal serta tenaga perencana masih ada dari non kesehatan dan masih ada yang belum pernah mengikuti pelatihan tentang perencanaan.

3. Untuk kegiatan penyusunan perencanaan Dinas Kesehatan Kabupaten Padang Pariaman sudah dianggarkan dana yang dialokasikan dalam anggaran APBD yang dimasukkan dalam Program Peningkatan Pengembangan Sistem Pelaporan Capaian Kinerja dan Keuangan.

4. Sarana dan prasarana yang mendukung penyusunan perencanaan Dinas Kesehatan Kabupaten Padang Pariaman sudah cukup memadai, namun pemeliharaan sarana dan prasarana masih kurang maksimal.

5. Data dan informasi dari puskesmas yang digunakan dalam penyusunan perencanaan sering terlambat dilaporkan serta masih diragukan kevalidan data tersebut terkait tenaga pengumpul maupun pengolah data bukan orang yang ahli dibidangnya.

\section{Saran}

1. Tenaga yang menangani/mengelola perencanaan perlu diberi pelatihan P2KT dan diharuskan membaca dan memahami undang-undang terkait dengan perencanaan.

2. Penempatan tenaga sesuai dengan bidang keahliannya.

3. Membentuk tim khusus pengolahan data dalam menguji kevalidan dan keakuratan data yang diketuai oleh Kepala Seksi Perizinan dan Evapor dan beranggotakan para pemegang program di Dinas Kesehatan Kabupaten Padang Pariaman.

\section{Daftar Pustaka}

Bakri, Hamzah., 2001. Penguatan Sistem Perencanaan Kesehatan Kabupaten/Kota. Disampaikan pada Pelatihan Perencanaan 
dan Penganggaran Kesehatan Terpadu (P2KT) Kabupaten/Kota Se Sulawesi Selatan Tahun 2001. Makasar.

Bappenas. 2009. Pembangunan Kesehatan dan Gizi di Indonesia: Overview dan Arah Kedepan. Background Study RPJMN 2010-2014. Jakarta.

Depkes RI, Badan Penelitian dan Pengembangan Kesehatan., 2008. Riset Kesehatan Dasar (Riskesdas) 2007: Laporan Nasional 2007. Jakarta.

Depkes RI., 2006. Rencana Strategis Departemen Kesehatan Tahun 2005-2009.

Ernawati, Ch. Tuty., 2004. Analisis Sistem Perencanaan dan Penganggaran Kesehatan di Dinas Kesehatan Kota Payakumbuh Provinsi Sumatera Barat Tahun 2004. Tesis. Universitas Indonesia, Jakarta.

Kuntjoro, T., 2004. Pertimbangan Kebutuhan Bisnis dan Kesiapan Organisasi Untuk Berubah Sebagai Dasar Pengambilan Keputusan Re Enginering Sebagai Strategi Peningkatan Mutu. Jurnal Manajemen Pelayanan Kesehatan, No 02/Juli 2004 hal 55-68. UGM, Yogyakarta.

LGSP, 2007. Seri Perencanaan Partisipatif: Penyusunan Perencanaan Pembangunan Daerah Bagi Eksekutif, Legislatif dan Organisasi Masyarakat Sipil (Bahan Pelatihan dan Pendampingan), Bagian 5: Rencana Kerja Satuan Kerja Perangkat Daerah. Jakarta.

Muninjaya, A.A. Gde., 2004. Manajemen Kesehatan. Edisi 2. EGC. Bandung.

Notoatmodjo, Soekidjo., 2007. Ilmu Kesehatan Masyarakat: Prinsip-prinsip
Dasar. Cetakan Kedua, Rineka Cipta, Jakarta.

Padang Pariaman, 2006. Rencana Pembangunan Jangka Menengah Daerah (RPJMD) Tahun 2006-2010. Dinas Kesehatan Kabupaten Padang Pariaman

Padang Pariaman, Dinkes., 2008. Rencana Strategis Dinas Kesehatan Kabupaten Padang Pariaman Tahun 2006-2010.

Padang Pariaman, Diskes., 2010. LPPD Dinas Kesehatan Kabupaten Padang Pariaman Periode 2006 s/d 2010

Riyarto, Sigit., Sukarna, \& Budiningsih, 2006. Analisis Kesiapan Dinas Kesehatan Dalam Mengalokasikan Anggaran Kesehatan Pada Era Desentralisasi. Jurnal Manajemen Pelayanan Kesehatan, Vol 09/No. 01/ Maret 2006, Hal 10-18. UGM, Yogyakarta.

Sumbar, Sekda Provinsi., 2008. Ekspose Akhir Tahun Gubernur Sumatera Barat: Dalam Rangka Laporan Penyelenggaraan Pemerintahan Daerah (LPPD) Tahun 2008 Provinsi Sumatera Barat. Padang.

Symond, Denas., 2006. Pengembangan Model Perencanaan dan Penganggaran Kesehatan Tahunan di Dinas Kesehatan Kota Padang Tahun 2006. Jurnal Kesehatan Masyarakat, Vol 02 / No. 01 / Sep 2007-Mar 2008 hal 116-123. Program Studi Ilmu Kesehatan Masyarakat Fakultas Kedokteran Universitas Andalas, Padang

Trisnantoro, L., 2001. Perubahan Sistem Kesehatan Wilayah Akibat Kebijakan Desentralisasi. Jurnal Manajemen Pelayanan Kesehatan, No. 02/April 2001, hal 93-100. UGM, Yogyakarta 
